\title{
The Effect of D-Penicillamine on Polymorphonuclear
}

\section{Leukocyte Function}

\author{
Hanna Chwalinska-Sadowska and John Baum \\ From the Arthritis and Clinical Immunology Unit, Monroe Community \\ Hospital, and the Department of Medicine, University of Rochester School of \\ Medicine and Dentistry, Rochester, New York 14603
}

A B S T R A C T D-Penicillamine, a reducing and chelating agent used in the treating of rheumatoid arthritis, was tested for its effects on polymorphonuclear leukocyte chemotaxis, phagocytosis, and lysosomal enzymes.

$\beta$-Glucuronidase release from polymorphonuclear leukocytes after phagocytosis of latex particles was not affected by D-penicillamine at concentrations ranging from 25 to $400 \mathrm{mg} /$ liter. No direct effect was seen on enzyme activity at the maximum concentration of the drug. There was no inhibition of latex particle ingestion. No cell damage was found at $400 \mathrm{mg} /$ liter penicillamine as measured by lactic dehydrogenase release. At this drug concentration there was only a $15 \%$ reduction in hemolytic complement levels.

Chemotaxis was significantly decreased at concentrations of $50 \mathrm{mg} /$ liter with a dose-dependent effect at higher concentrations which showed a plateau from 200 to $400 \mathrm{mg} /$ liter.

The parent compound D-cysteine was also tested in these systems. The same lack of effect on phagocytosis and enzyme release was found. D-Cysteine did inhibit chemotaxis but to a lesser degree than D-penicillamine.

This dicotomy of drug effect may indicate that the beneficial action of $\mathrm{D}$-penicillamine in the treatment of rheumatoid arthritis is due to the decreased chemotaxis of polymorphonuclear leukocytes into the joint, while the absence of an effect on phagocytosis and lysosomal enzymes shows the cells can still function to ingest and destroy bacteria. This latter effect correlates with the absence of infection in patients treated with this compound.

\section{INTRODUCTION}

Since the paper describing the use of $\mathrm{D}$-penicillamine in the treatment of rheumatoid arthritis by Jaffe, there

Dr. Chwalinska-Sadowska's present address is the Institute of Rheumatology, Warsaw, Poland.

Received for publication 29 December 1975 and in revised form 28 May 1976. have been several studies reporting the beneficial effects of penicillamine in rheumatoid arthritis (RA) ${ }^{1}$ (1-3). More recently a double-blind trial was conducted in England by a combined clinic group (4). Their results supported the beneficial effects found in the earlier uncontrolled trials of D-penicillamine therapy. There was found a significant improvement in disease activity with a notable decrease in joint activity. The most common adverse reactions including rash, G. I. disturbances, leukopenia, thrombocytopenia, and proteinuria usually responded to withdrawal of the drug. D-Penicillamine thus appears to be an effective, relatively safe agent for the treatment of RA. The immunosuppressive drugs used for long-term treatment of RA such as the immunosuppressives (cyclophosphamide, azathioprine, and chlorambucil) show a tendency to promote the development of infection in treated patients but this problem has not been reported during therapy with D-penicillamine. This side effect is particularly important because of the higher frequency of infection that is present de novo in patients with RA (5). Since patients treated with $\mathrm{D}$-penicillamine are spared this complication, we felt a study of D-penicillamine in relation to granulocyte function might show how this drug could favorably influence the course of RA while leaving intact the body's ability to handle infection. The specific aim of these studies, therefore, was to look at the in vitro effect of D-penicillamine on human polymorphonuclear leukocyte chemotaxis and phagocytosis. Since D-cysteine has basically the same structure as penicillamine the experiments were done with both drugs at the same concentrations. Any differences found between the effect of penicillamine and cysteine on leukocyte function might then

\footnotetext{
${ }^{1}$ Abbreviations used in this paper: $\mathrm{CH}_{50}$, total hemolytic complement activity; F-II, Cohn Fraction II; HBSS, Hanks' balanced salt solution; LDH, lactic dehydrogenase; PMN, polymorphonuclear neutrophils; RA, rheumatoid arthritis.
} 
provide some measure of the specific effect of penicillamine.

\section{METHODS}

Cells. In the course of these experiments polymorphonuclear neutrophils (PMN) were obtained from the blood of 20 normal, healthy laboratory personnel, and from $10 \mathrm{pa}-$ tients with RA. All RA patients were rheumatoid factor positive. In seven of the patients the titer was equal to or greater than $1: 5,120$; in two the titer was $1: 320$; and in one. $1: 160$. The individuals own cells were always used as the controls during the course of the experiments.

Preparation of leukocytes. $40 \mathrm{ml}$ of blood was obtained in heparinized Vaccutainer tubes (Becton-Dickinson \& Co., Rutherford, N. J.). $20 \mathrm{ml}$ of the blood was spun for 10 min at 2,000 rpm to obtain plasma. To the $20 \mathrm{ml}$ of remaining blood was added $1.5 \mathrm{ml}$ of $2 \%$ methyl cellulose. After mixing, the blood was allowed to settle for $60 \mathrm{~min}$ at room temperature. The cell-rich plasma was placed into plastic tubes and mixed with an equal volume of Hanks' balanced salt solution (HBSS) and washed twice. The final cell button was resuspended in 25\% plasma and HBSS to obtain a final cell count of $5 \times 10^{8}$ cells $/ \mathrm{ml}$ dilutent.

Drugs. D-Penicillamine was obtained through the courtesy of Dr. Robert Thompson of Merck Sharp \& Dohme Research Laboratories, West Point, Pa. It was supplied as the base without the addition of any preservatives. D-Cysteine hydrochloride monhydrate was obtained from ICN Nutritional Biochemicals Div., International Chemical \& Nuclear Corp., Cleveland, Ohio. Most studies were performed at concentrations of $0,25,50,100$, and $400 \mathrm{mg} / \mathrm{liter}$ with both drugs. An additional concentration of $12.5 \mathrm{mg} /$ liter was prepared for some chemotaxis experiments.

Preparation of latex particles. The latex particles (diameter $1.011 \mu \mathrm{m}$ ) were obtained from The Dow Chemical Company, Indianapolis, Ind. They were prepared for use by the method of Kvarstein (6). A $1 \%$ solution in HBSS was used. $0.1 \mathrm{ml}$ of this solution was added to $5 \times 10^{8}$ leukocytes in $2 \mathrm{ml}$ of medium.

Enzy'me assays. $\beta$-Glucuronidase was selected as the lysosomal enzyme to be measured following the observations of Hawkins and Peeters (7) who found that of all the lysosomal enzymes that they measured, $\beta$-glucuronidase was the best indicator of lysosomal activity. The method of $\beta$-glucuronidase measurement was that of Fishman (8).

$0.1 \mathrm{ml}$ of sample was added to a tube containing $0.1 \mathrm{ml}$ of substrate (phenolphthalein glucuronide) and $0.8 \mathrm{ml}$ of 0.1 $\mathrm{M}$ acetate buffer, $\mathrm{pH}$ 4.5. A control was set up for each sample containing $0.1 \mathrm{ml}$ substrate and $0.8 \mathrm{ml}$ of buffer. A blank containing $0.1 \mathrm{ml}$ substrate and $0.8 \mathrm{ml}$ of buffer was also prepared. All the tubes were incubated for $18 \mathrm{~h}$ at $38^{\circ} \mathrm{C}$. The reaction was stopped by the addition of $2.5 \mathrm{ml}$ of alkaline glycine solution, $1.0 \mathrm{ml} 5 \%$ TCA, and $1.5 \mathrm{ml}$ distilled water.

Optical density was read at $540 \mathrm{~nm}$. The percent of total activity of $\beta$-glucuronidase in the medium was obtained by dividing the activity of $\beta$-glucuronidase in the medium by the total activity of the resting cells.

Lactic dehydrogenase (LDH) was measured by the method of Wróblewski and LaDue (9). LDH activity was measured as a means of identifying any destructive effects on the intact cell, since as a cytoplasmic enzyme it would only be released if there were damage to the cell membrane. To measure LDH, $0.1 \mathrm{~cm}^{3}$ of sample was added to a tube

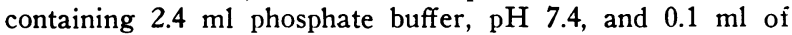
DPNH. The tubes were incubated for $20 \mathrm{~min}$ at room temperature. $0.1 \mathrm{ml}$ of sodium pyruvate was added at time zero. The change in optic density after $3 \mathrm{~min}$ was used to express the percent of total activity of LDH in medium with resting cells and after phagocytosis.

Phagocytosis expcriments. The various concentrations of D-penicillamine and D-cysteine were prepared in $0.5 \mathrm{ml}$ of HBSS. To this was added $0.5 \mathrm{ml}$ of autologous plasma. In the control tube, $0.5 \mathrm{ml}$ of HBSS was substituted for the solution of drug.

This material was then mixed with $1.0 \mathrm{ml}$ of cell suspension to obtain the final drug concentrations in the respective tubes. Therefore, the final volume of cell suspension was $2.0 \mathrm{ml}$ containing $5.0 \times 10^{8}$ cells and the final plasma concentration in the medium was $36 \%$. The $\mathrm{pH}$ of the medium with each drug at $400 \mathrm{mg} / \mathrm{liter}$ was 7.5 .

After a 15-min prior incubation of the drug and the PMN at $37^{\circ} \mathrm{C}, 0.1 \mathrm{ml}$ of a $1 \%$ solution of polystyrene latex particles in HBSS was added to tubes with and without the drug. An additional tube for resting cells was prepared in which HBSS was substituted for the solution of drug and latex particles. The cells were then incubated with the polystyrene latex particles for $60 \mathrm{~min}$ at $37^{\circ} \mathrm{C}$ in a constantly revolving rotor in plastic tubes. The PMN were then spun for $10 \mathrm{~min}$ at $1,250 \mathrm{rpm}$ and the supernates were removed and used for the enzyme studies. No remaining cells were observed in the supernate after spinning. The cell button was then resuspended in $2.0 \mathrm{ml}$ of $0.34 \mathrm{M}$ sucrose plus $0.1 \mathrm{ml}$ of $2 \%$ Triton X (Rohm \& Haas Co., Philadelphia, $\mathrm{Pa}$.). (The final concentration of Triton was $1 \%$ ). This was mixed thoroughly on a vortex and incubated for $10 \mathrm{~min}$ at $37^{\circ} \mathrm{C}$. After this, the material was spun for $20 \mathrm{~min}$ at $11,000 \mathrm{rpm}$ at $4^{\circ} \mathrm{C}$. The supernates of this material were also used for enzyme measurements.

The measurements of $\beta$-glucuronidase release from PMN after phagocytosis were performed by preincubation of the cells with the D-penicillamine and D-cysteine before the polystyrene latex particles were added. The total incubation period for measurement of the release of $\beta$-glucuronidase after ingestion of particles was $60 \mathrm{~min}$. This time was used following the studies of Ignarro et al. who found that $\beta$ glucuronidase release increased with time after phagocytosis with the curve flattening at $40 \mathrm{~min}(10)$. The concentration of polystyrene :atex particles used per cell and the duration of uptake were based upon the studies of Kvarstein (11). The concentration was approximately $100-120$ particles per polymorphonuclear leukocyte. Kvarstein also showed that the uptake of particles went rapidly to a maximum with a plateau at about $15 \mathrm{~min}$. The time duration for both the latex particles, phagocytosis, and drug exposure were based upon the optimum levels found in these two studies.

To determine the effect of penicillamine on the uptake of latex particles, slides were made with PMN after a 60 min incubation with latex particles in the absence and presence of the maximum dosage of D-penicillamine $(400 \mathrm{mg} /$ liter). The slides were stained with Wright's stain and the cells checked for latex particle uptake.

Latex particle uptake was measured in the absence of penicillamine and in the presence of concentrations of 100 and $400 \mathrm{mg} /$ liter. At each concentration 100 cells were counted in two separate runs. The number of particles per cell was counted by light microscopy.

As a further control, the agents used in the preparations were studied for any direct effect on the enzyme activity in the plasma. D-Penicillamine and D-cysteine were added at the maximum concentration $400 \mathrm{mg} / \mathrm{liter}$ and compared to zero concentration. The plasma was incubated with this concentration of drugs for $75 \mathrm{~min}$ and $\beta$-glucuronidase and 
$\mathrm{LDH}$ measurements were made and compared with the control which were incubated without these materials. The latex particles were also used as controls and again incubations were carried out for $75 \mathrm{~min}$ with the polystyrene latex and compared to the plasma without this material.

Chemotaxis. The cells for this assay were obtained with our standard method (12). The cell suspensions containing the drug and the drug-free control were prepared in the same manner as for phagocytosis. After a 60 -min incubation with the drug the cells were spun onto cellulose membrane filters (Schleicher \& Schuell, Inc., Keene, N. H.) and placed in chemotaxis chambers (Bellco Glass, Inc., Vineland, N. J.). In the top portion of the chamber, HBSS was placed. To the bottom section $(0.12 \mathrm{ml})$ was added a mixture containing 20\% (vol/vol) human serum and aggregated Cohn Fraction II (F-II) $1 \mathrm{~g} /$ liter. A control for each sample was prepared with aggregated F-II along in $1 \mathrm{~g} /$ liter HBSS in the bottom section $(0.12 \mathrm{~m})$.

The chambers were incubated for $3 \mathrm{~h}$ at $37^{\circ} \mathrm{C}$. The membrane filters were removed and stained by Boyden's method. The cells were counted with semi-automated counting system (PIMC particle counter, Millipore Corp., Bedford, Mass.) (13). The chemotactic index was then calculated. Each experiment was done in triplicate.

Several experiments were performed incubating the chambers for $1 \mathrm{~h}$. Although a concentration effect was noted with this short incubation period, the chemotactic index was not as high as when the cells were incubated for our standard 3-h period. Therefore, the 3-h incubation was used to provide a better measurement at the different concentrations.

To determine the effect of penicillamine on complement activation, experiments were done in which serum was mixed with D-penicillamine so that the final concentration of the D-penicillamine was $400 \mathrm{mg} / \mathrm{liter}$. This was the maximum concentration used in the phagocytosis and chemotaxis experiments. This mixture was then incubated at $37^{\circ} \mathrm{C}$ for 75 min along with a control in which HBSS was added in the same volume. Measurements of total hemolytic complement activity $\left(\mathrm{CH}_{50}\right)$ were made after the incubation. Five separate sera were used for these experiments.

To determine the effect on complement by prolonged in vitro exposure to D-penicillamine, normal human serum was mixed with varying concentrations of $D$-penicillamine and incubated up to $72 \mathrm{~h}$ at $37^{\circ} \mathrm{C}$. Aliquots were taken at $24-\mathrm{h}$ intervals. The treated serum was then mixed with aggregated F-II for the induction of chemotactic factors from the penicillamine exposed complement. Each run at the different concentrations was performed using the same sera. The concentrations of penicillamine used were the control ( 0 concentration), $5 \mathrm{mg} /$ liter, $10 \mathrm{mg} /$ liter, $25 \mathrm{mg} /$ liter, and $50 \mathrm{mg} /$ liter.

Statistical analysis for these studies were done using the Wilcoxon signed rank sum test for paired replicates. When unpaired tests were used the Wilcoxon rank sum test was used. $P$ values of 0.05 or less were considered significant for these experiments. A regression line was fitted to the mean responses (in log chemotactic index units) at the various concentrations for both the D-penicillamine and cysteine. The analysis for the effects of $D$-penicillamine and $D$ cysteine on chemotaxis was performed by analysis of variance.

\section{RESULTS}

Table I shows the results obtained in studies of the chemotaxis of PMN with concentrations ranging from
TABLE I

Effect of D-Penicillamine on Chemotaxis of PMN

\begin{tabular}{|c|c|c|c|c|}
\hline \multirow[b]{2}{*}{$n$} & \multirow{2}{*}{$\begin{array}{l}\text { D-Penicil- } \\
\text { lamine }\end{array}$} & \multicolumn{2}{|c|}{ Chemotactic index } & \\
\hline & & Agg IgG* & Agg IgG $+C$ & \\
\hline & mg/liter & \multicolumn{2}{|c|}{$. M e a n \pm S E . M$} & $P$ \\
\hline 30 & 0 & $76 \pm 10$ & $426 \pm 56$ & \\
\hline 13 & 12.5 & $75 \pm 11$ & $603 \pm 103$ & $<0.05$ \\
\hline 16 & 25 & $63 \pm 10$ & $519 \pm 83$ & NS \\
\hline 30 & 50 & $74 \pm 10$ & $319 \pm 43$ & $<0.01$ \\
\hline 30 & 100 & $73 \pm 9$ & $243 \pm 31$ & $<0.01$ \\
\hline 17 & 200 & $66 \pm 10$ & $190 \pm 38$ & $<0.01$ \\
\hline 15 & 400 & $59 \pm 8$ & $175 \pm 48$ & $<0.01$ \\
\hline
\end{tabular}

${ }^{*} P, \mathrm{NS}$ at all concentrations.

12.5 to $400 \mathrm{mg} /$ liter for D-penicillamine and in Table II for D-cysteine from 50 to $400 \mathrm{mg} /$ liter.

No significant effect (when compared to the control) was seen at the $25 \mathrm{mg} /$ liter concentration of D-penicillamine, although there was stimulation at $12.5 \mathrm{mg} /$ liter $(P<0.05)$. A significant decrease of chemotaxis of the PMN was seen starting at a concentration of $50 \mathrm{mg} /$ liter and a more pronounced effect at the higher concentrations. There was a plateau as the higher concentrations were reached and this can be seen graphically in Fig. 1. The data showing the means \pm SEM with the number of experiments for each concentration is shown in Table I. In this table are also seen the values when aggregated gamma globulin only was present. Aggregated gamma globulin alone in the absence of complement showed no chemotactic effect. It is noted that the chemotactic values for the cells in these experiments without chemotactic stimulation showed no change with increasing drug concentrations. The constant values for the chemotactic index shows that D-penicillamine will not act to inhibit random migration even at concentrations up to $400 \mathrm{mg} /$ liter.

At the same concentrations of D-cysteine it can be seen in Fig. 1 (and Table II) that the inhibitory affect of this drug was not demonstrated until concentrations

TABLE II

Effect of D-Cysteine on Chemotaxis of PMN

\begin{tabular}{ccccc}
\hline & \multicolumn{4}{c}{ Chemotactic index } \\
\cline { 3 - 4 }$n$ & D-Cysteine & Agg IgG & Agg IgG +C & \\
\hline \multicolumn{4}{c}{ mg/liter } & \multicolumn{2}{c}{ Mean \pm SEM } & $P$ \\
11 & 0 & $66 \pm 24^{*}$ & $583 \pm 133$ & \\
10 & 50 & $92 \pm 18$ & $587 \pm 140$ & NS \\
11 & 100 & $63 \pm 10$ & $407 \pm 80$ & $<0.1$ \\
11 & 200 & $66 \pm 18$ & $271 \pm 52$ & $<0.01$ \\
11 & 400 & $68 \pm 15$ & $294 \pm 58$ & $<0.01$ \\
\hline
\end{tabular}

${ }^{*} P, \mathrm{NS}$ at all concentrations. 


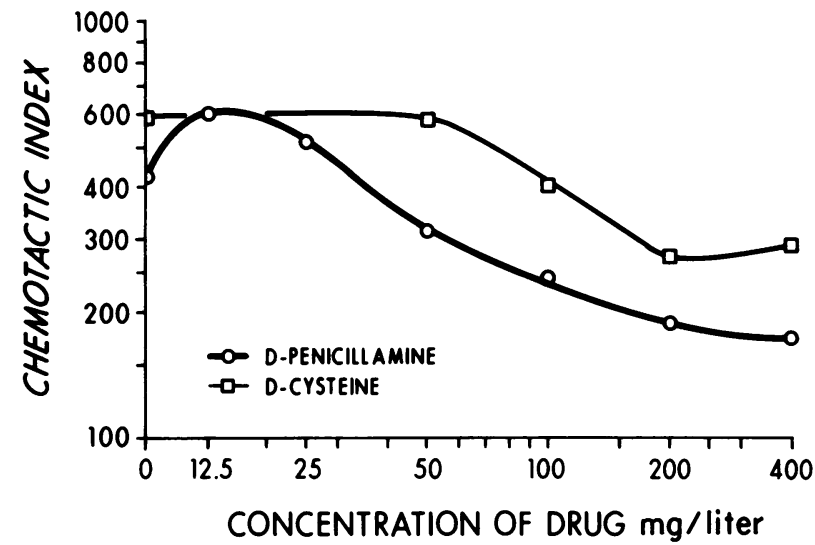

Figure 1 Effect of D-penicillamine and D-cysteine on polymorphonuclear leukocyte chemotaxis.

of $100 \mathrm{mg} /$ liter were reached. The effect on random migration was the same as that seen with D-penicillamine (Table II). The relationship of similar concentrations of D-cysteine and D-penicillamine are seen in Fig. 1.

Estimates of dosage affects on chemotaxis were made by setting up a computer program that would also take into account day to day variation and a model prepared for the data. When the responses were plotted against levels of D-penicillamine over the range of dosages from 12.5 to $400 \mathrm{mg} /$ liter, the response was approximately linear. A regression line was fitted to the mean responses. Analysis showed that there were very significant dosage affects when compared to the controls. The affect among the dosage groups were linear with a low concentration ( $12.5 \mathrm{mg} /$ liter ) showing higher chemotactic indices than controls and higher concentrations with lower chemotactic indices than controls. For cysteine there were similar findings, but there was significantly less effect of D-cysteine on chemotaxis at dosages 100,200 , and $400 \mathrm{mg} /$ liter. The response to the D-cysteine was also linear with the slope not significantly different from that found with D-penicillamine, indicating that the effect of both drugs on chemotaxis was similar although less marked with D-cysteine. With both drugs the effect seemed to level off at 200 to $400 \mathrm{mg} / \mathrm{liter}$ dosage level.

TABLE III

Chemotaxis after Complement Incubation with D-Penicillamine for Prolonged Periods

\begin{tabular}{cccccr}
\hline $\begin{array}{c}\text { Duration } \\
\text { of } \\
\text { incubation }\end{array}$ & \multicolumn{5}{c}{ Final D-penicillamine concentration } \\
\cline { 2 - 6 } & 0 & 5 & 10 & 25 & 50 \\
\hline$h$ & & & $m g / l i t e r$ & & \\
24 & 170 & 136 & 228 & 245 & 72 \\
48 & 265 & 479 & 319 & 274 & 325 \\
72 & 655 & 760 & 514 & 600 & 605 \\
\hline
\end{tabular}

TABLE IV

The Effect of D-Penicillamine and D-Cysteine on $\beta$-Glucuronidase Release from Phagocytosing PMN

\begin{tabular}{|c|c|c|c|}
\hline \multirow{3}{*}{$\begin{array}{l}\text { Drug } \\
\text { concen- } \\
\text { tration }\end{array}$} & \multicolumn{3}{|c|}{ Percent of total activity of $\beta$-glucuronidase in medium } \\
\hline & \multicolumn{2}{|c|}{ D-Penicillamine } & \multirow{2}{*}{$\begin{array}{c}\text { D-Cysteine } \\
\text { Normals* }\end{array}$} \\
\hline & Normals* & RA $\ddagger$ & \\
\hline$m g / l i t e r$ & \multicolumn{3}{|c|}{$M e a n \pm S E M$} \\
\hline 0 & $33.6 \pm 2.5$ & $33.1 \pm 2.4$ & $31.8 \pm 1.6$ \\
\hline 25 & $35.1 \pm 4.0 \S$ & $34.8 \pm 2.8$ & $26.7 \pm 1.4 \|$ \\
\hline 50 & $34.4 \pm 3.3$ & $34.2 \pm 1.9$ & $30.9 \pm 1.4$ \\
\hline 100 & $33.3 \pm 2.9$ & $34.5 \pm 2.7$ & $31.0 \pm 1.5$ \\
\hline 200 & $33.2 \pm 2.8$ & $33.1 \pm 2.0$ & $31.3 \pm 2.2$ \\
\hline 400 & $34.2 \pm 2.4$ & $32.8 \pm 1.9$ & $32.3 \pm 1.4$ \\
\hline
\end{tabular}

* 15 experiments. $\ddagger 10$ experiments. $\$ 8$ experiments. || 5 experiments.

The statistical analysis of the chemotaxis data was performed by Professor W. Jackson Hall, Department of Biostatistics, University of Rochester.

Since the chemotaxis method depends upon the activation of serum chemotactic factors by complement activation we performed several studies to measure the direct effect of D-penicillamine on complement. Table II shows that at the higher concentrations of D-penicillamine there was a reduction of about $10-14 \%$ of the $\mathrm{CH}_{50}$ at maximum drug levels. This would be insufficient to account for the total effect of chemotaxis inhibition.

To measure the effect of prolonged exposure of penicillamine on complement activation, penicillamine at concentrations from 0 to $50 \mathrm{mg} /$ liter was incubated with a normal serum for periods up to $72 \mathrm{~h}$ before this serum was used as the source of chemotactic factors.

It is shown in Table III that there was no difference at any of the penicillamine concentrations used on chemotaxis for any one of the time periods when compared to the control. It was of interest to note that at $72 \mathrm{~h}$ there appeared to be the maximum stimulatory effect by the chemotactic factors. However, this was not dependent on the presence of penicillamine.

Table IV shows the results of studies looking for any effect of D-penicillamine and D-cysteine on $\beta$-glucuronidase release from polymorphonuclear leukocytes phagocytosing polystyrene latex particles. The results are expressed as the percent of the total activity of $\beta$-glucuronidase in the medium. Studies were performed with cells from patients with RA as well as with cells from normal controls. With drug concentrations up to $400 \mathrm{mg} / \mathrm{liter}$ there was no effect of D-penicillamine on the release of $\beta$-glucuronidase from phagocytosing cells. This was true 
TABLE V

PMN Phagocytosis of Latex Particles after Incubation with D-Penicillamine

\begin{tabular}{ccccc}
\hline \multirow{2}{*}{$\begin{array}{c}\text { Concen- } \\
\text { tration of } \\
\text { D-penicil- } \\
\text { lamine }\end{array}$} & \multicolumn{4}{c}{ Number of particles/cell } \\
\cline { 2 - 5 }$m g /$ liter & 0 & $1-4$ & $5-8$ & $9-16$ \\
0 & $30^{*}$ & 30 & 31 & 10 \\
100 & 28 & 14 & 44 & 17 \\
400 & 29 & 24 & 30 & 19 \\
\hline
\end{tabular}

* Number of cells counted.

with cells from both normals and from patients with RA.

In a number of experiments, $60 \mathrm{~min}$ after the ingestion of latex particles, cells were stained with Wright's stain to observe the uptake of latex particles in the presence or absence of the maximum concentration of penicillamine ( $400 \mathrm{mg} / \mathrm{liter})$. No difference in uptake was found when the drug was present. This study was performed to insure that the enzyme release was actually related to the uptake of the latex particles.

Although gross visual observation showed no difference in latex particle uptake at zero concentration and at maximum penicillamine concentration of $400 \mathrm{mg} /$ liter, several experiments were performed in which counts of the ingested latex particles were made in the presence of no penicillamine, $100 \mathrm{mg} / \mathrm{liter}$, and $400 \mathrm{mg} /$ liter. Table $\mathrm{V}$ shows the distribution of particles in the polymorphonuclear leukocytes. There is no discernible difference either in the absence of penicillamine or at the intermediate or maximum concentrations.

D-Cysteine showed similar findings with virtually no change in the release of $\beta$-glucuronidase as a result of phagocytosis in the presence of this drug.

LDH activity was studied as an indicator of any toxic effect of these drugs on the cells. Since LDH is a cytoplasmic enzyme. one would expect that if there were to be any direct toxic effect of D-penicillamine or D-cysteine then the concentration of LDH in the medium would increase in the presence of these drugs and even more so if there were to be a dose-related effect. In Table VI it can be seen that neither D-penicillamine nor D-cysteine
TABLE VI

The Effect of D-Penicillamine and D-Cysteine on Lactic Dehydrogenase Release from Phagocytosing PMN

\begin{tabular}{|c|c|c|}
\hline \multirow{2}{*}{$\begin{array}{l}\text { Drug } \\
\text { concen- } \\
\text { tration }\end{array}$} & \multicolumn{2}{|c|}{ Percent of total activity of LDH medium* } \\
\hline & D-Penicillamine & D-Cysteine \\
\hline $\mathrm{mg} / \mathrm{liter}$ & \multicolumn{2}{|c|}{$M e a n \pm S E M$} \\
\hline 0 & $28.5 \pm 1.8$ & $29.2 \pm 2.8$ \\
\hline 25 & $30.1 \pm 2.5$ & $32.6 \pm 1.2 \ddagger$ \\
\hline 50 & $28.5 \pm 2.5$ & $29.0 \pm 2.3$ \\
\hline 100 & $27.8 \pm 1.8$ & $27.7 \pm 2.3$ \\
\hline 200 & $28.1 \pm 2.1$ & $25.9 \pm 2.5$ \\
\hline 400 & $29.0 \pm 1.3$ & $29.4 \pm 2.4$ \\
\hline
\end{tabular}

* Mean of 11 experiments.

$\ddagger$ Mean of 3 experiments.

had any affect on the cells to cause release of this enzyme.

Our standard method for chemotaxis (14) has been to use a 3-h incubation period. Since the phagocytosis experiments normally use a shorter incubation period, (i.e., $1 \frac{1}{2} \mathrm{~h}$ ), we performed a set of experiments with chemotaxis using this shorter time period. At a concentration of $400 \mathrm{mg} /$ liter of D-penicillamine the chemotactic index was $54 \%$ of the control. This shows that even with the shorter chemotaxis period D-penicillamine demonstrated an inhibitory affect.

It should be noted that with chemotactic experiments, the cells were exposed to the D-penicillamine for $60 \mathrm{~min}$. After they were placed on the membrane filter no additional penicillanine was added. Although some penicillamine would be present on the filter, the solution is almost completely absorbed by the absorbant pads used during the centrifugation process. The amount remaining on the filter was calculated to be $5 \times 10^{-4}$ of the total chamber volume (by the weight of fluid remaining in the filter). Thus, the effect of the penicillamine was that present in the initial incubation and whatever was present on the cell surfaces and not due to any D-penicillamine in the medium in the chamber during chemotaxis. The phagocytosis experiments, on the other hand, were carried out for the total incubation period with the full concentration of the drug present in the medium.

The possibility existed that in the presence of mercap-

TABLE VII

Direct Effect of D-Penicillamine, D-Cysteine, and Polystyrene Latex on Enzyme Activity in Plasma

\begin{tabular}{lcccccc}
\hline & \multicolumn{3}{c}{ D-Penicillamine } & \multicolumn{2}{c}{ D-Cysteine } & \multicolumn{2}{c}{ Polystyrene latex (0.05\%) } \\
\hline & & & mg/liter & & & \\
& 0 & 400 & 0 & 400 & Absent & Present \\
$\beta$-Glucuronidase $(O D)$ & 0.050 & 0.050 & 0.046 & 0.042 & 0.069 & 0.073 \\
LDH $(I U)$ & 96 & 97 & 115 & 120 & 62 & 60 \\
\hline
\end{tabular}


TABLE VIII

Effect of D-Penicillamine on Complement Activation

\begin{tabular}{cc}
\hline D-Penicillamine & $\begin{array}{c}\text { Activity of } \\
\text { control } \mathrm{CH}_{\mathrm{b0}}\end{array}$ \\
\hline$m g /$ liter & $\%$ \\
50 & 98.7 \\
200 & 88.6 \\
400 & 85.0 \\
\hline
\end{tabular}

tans (D-penicillamine and D-cysteine) there might be a direct affect on enzyme function. A series of control experiments were performed to measure the direct effect of D-penicillamine and D-cysteine on the activity of $\beta$-glucuronidase and LDH. We also considered that the latex particles might also have a similar effect (to depress measured enzyme) perhaps because of absorption of the enzyme material and experiments were also made to measure these enzymes in the presence or absence of the polystyrene latex particles. As indicated in the Methods, these measurements were made on enzyme activity present in plasma.

Table VII shows that at maximum concentrations of D-penicillamine and D-cysteine there was no measurable effect on the activity of $\beta$-glucuronidase and LDH. In addition it was also found there was no effect of polystyrene latex particles on the activity of these enzymes. The concentration of latex particles used was the same concentration as those used during the course of the experiments.

As a further control, several experiments were performed to measure the direct effect of penicillamine on complement activation. In Table VIII it can be seen that at concentrations of penicillamine up to a maximum of $400 \mathrm{mg} /$ liter there was a slight drop in total complement activity up to a maximum of $15 \%$ loss at this level. Even at these maximum concentrations there is seen to be only a minimal effect of penicillamine on complement activity.

\section{DISCUSSION}

The rationale for the use of D-penicillamine in the treatment of RA was based upon the observation that this drug acted as a dissociation agent on the disulfide bonds of rheumatoid factor (15).

Subsequent studies have shown that D-penicillamine is an inhibitor of lymphocyte transformation and by this means will decrease immunoglobulin production (16). It should be pointed out that in the work done by Roath and Wills (16), inhibition of lymphocyte transformation was not seen until a concentration of $600 \mathrm{mg} / \mathrm{liter}$ was reached. When they used 200 and $400 \mathrm{mg} /$ liter (the levels used in our study) no effect was noted on the cell activity. They noted that at concentrations up to 1,000 $\mathrm{mg} /$ liter lymphocytes were inert but relatively undamaged. This effect on lymphocyte function was interpreted by them as a clear demonstration of the effect of D-penicillamine as an immunosuppressive agent. Though this experimental evidence exists, Huskisson and Berry (17) found no evidence of any in vivo change which could correlate with an effect of D-penicillamine on thymus-derived $(\mathrm{T})$ lymphocytes. They did not find any suppression of responsiveness to interdermal tuberculin or Keyhole limpet hemocyanin while their patients were taking this drug.

Liyanage and Currey (18) found no effect on delayed hypersensitivity or on humoral reactions when D-penicillamine was given to rats orally in doses 10 times greater than have been used in studies in humans. They also found that adjuvant arthritis was not affected by D-penicillamine.

Specific immunoglobulin levels have been demonstrated to fall after treatment with D-penicillamine since Bluestone and Goldberg (19) reported that IgG, IgM, and $\operatorname{IgA}$ fell during the course of treatment. These differences may be either due to the varying effects of drug concentration or to the cumulative effect of the drug. Although there is little data on the blood levels required for the action of penicillamine in the treatment of RA, some estimates have been made. Blood levels of roughly $25-30 \mathrm{mg} / \mathrm{liter}$ are considered to be in the therapeutic range. ${ }^{2}$ However, no data is available on measurements of penicillamine levels during the course of therapy.

Cysteine was used to see if the properties of D-penicillamine were due solely to its mercaptan structure since this is identical in both compounds. Some of their effects differ since D-penicillamine has been shown to inhibit polio virus RNA synthesis at concentrations ranging from 100 to $1,000 \mathrm{mg} /$ liter, while D-cysteine hydrochloride did not show this same inhibitory effect (20). We found in our chemotaxis experiments that D-cysteine showed quantitatively less inhibition.

Penicillamine is a derivative of D-cysteine ( $\beta$ - $\beta$-dimethylcysteine). Although a mercaptan D-cysteine has activity which is somewhat different from penicillamine since as indicated above, this compound does not show the antipolio virus effect shown by penicillamine. DLCysteine hydrochloride has been shown to inhibit the development of adjuvant arthritis in the rat (21). This is another indication that cysteine (or similar mercaptan compounds) has an effect on inflammatory (cellular?) function. Cysteine has also been found to inhibit blastic transformation of lymphocytes at concentrations of $300 \mathrm{mg} /$ liter. This dosage is within the levels used in our study (22).

Jaffe has pointed out that the effects on bone marrow that have been reported with penicillamine are not the

\footnotetext{
${ }^{2}$ Jaffe, I. A. Personal communication.
} 
same as those seen with cyclophosphamide or azothioprine. In the case of penicillamine the effect on the bone marrow appears to be a hypersensitivity reaction to the drug and not to any direct effect on the marrow. This probably accounts for the usual reversibility of the hemotologic side effects after treatment of patients with penicillamine (23).

It was recently claimed in studies of penicillamine in the treatment of arthritis that the effect was due purely to a suppressive effect on the lymphocytes (24). Lymphocyte counts were significantly lower in patients treated with penicillamine with a diminution of $\mathrm{T}$ and bone marrow derived (B) lymphocytes. In comparison with the patients given penicillamine, steroids, and cyclophosphamide, the patients on penicillamine and steroids had a normal to increased number of granulocytes in the blood, while, as would be expected, patients treated with cyclophosphamide showed significantly lower granulocyte counts. The authors considered the effect on the lymphocytes by D-penicillamine to be immunosuppressive.

A major point which is demonstrated by our results is the dicotomy of the effect of penicillamine on the function of the polymorphonuclear leukocyte. It is inhibitory for chemotaxis. Chemotaxis defined as directed migration of the cell in response to a chemotactic stimulus (25) may be affected by several mechanisms, e.g., metabolism of the cell before phagocytosis (12), deficiency of the attractant (26), or the presence of a chemotactic factor inactivator (27). However, it was seen that there was no effect on random migration even at the maximum concentrations used (Table I). This shows that D-penicillamine has a specific effect on the cell during its reaction to a chemotactic stimulus. Since there was no effect on random migration it may be a specific effect on the interaction between the chemotactic attractant and a receptor site on the membrane of the polymorphonuclear leukocyte.

The effect of penicillamine on the PMN appears to be quite similar to the effect we have seen with a specific complement deficiency. Alper et al. (28) have reported a patient with a homozygous C3 deficiency. This patient had a defect in both phagocytosis and chemotaxis both of which were corrected by the addition of $\mathrm{C} 3$ to her serum. On the other hand, we have studied a patient with C5 deficiency who, though showing a profound impairment of chemotaxis, showed normal phagocytosis (26). This patient shows frequent recurring and extensive infections (mostly cutaneous) (26). Therefore, the effect of penicillamine is similar to that seen in a patient with C5 deficiency but unlike the features of C3 deficiency. Becker (29) has suggested that chemotaxis occurs by the activation of proesterase present on the membrane of the cell. Once this proesterase is activated subsequent reactions are triggered, resulting in movement of the cell in the direction of the site at which the proesterase was activated. Based on this theory there is a strong possibility that the penicillamine action on the cell membrane may be by a dose-dependent inhibition of proesterase activation.

Another possible explanation for the inhibition of chemotaxis by penicillamine would be a direct effect of the penicillamine on complement activation although phagocytosis is enhanced by activated $\mathrm{C} 3(\mathrm{C} 3 \mathrm{~b})$ and C5 (C5b) (30). This appears to be unlikely, since in the phagocytosis experiments there was direct exposure to the various concentrations of the drug for the period during which the incubation and phagocytosis with the latex particles took place. No effect was seen on phagocytosis in spite of the continuous presence of the drug.

In the chemotaxis experiments the exposure to the drug was only maintained at the experimental concentration during the preincubation period of $15 \mathrm{~min}$. After this the cells were spun down on the membrane filter, the fluid being absorbed by an absorbant pad. Although some penicillamine would remain on the membrane, the volume was fractional and is diluted by the serum and HBSS which was then placed into the chamber. The same complement factors are involved in chemotaxis although another split fragment is involved (C3a and C5a). Thus is would be unlikely for the marked effect seen with chemotaxis to be due to complement interference which in these experiments involves a shorter exposure to the penicillamine and cannot be seen with phagocytosis where the exposure to the penicillamine occurred in higher concentrations for at least four times as long. The direct effect of penicillamine on total complement activation $\left(\mathrm{CH}_{30}\right)$ was found at the higher concentrations but appeared to be a minimal effect.

It appears that the effect of penicillamine causing the inhibition of chemotaxis is due to a direct effect of penicillamine on the cell membrane.

Phagocytosis is a more complicated function of the polymorphonuclear leukocyte and under the conditions of the experiment penicillamine would be taken into the cell with the latex particle in the phogosome. This could occur by adsorption of the material on the latex particle or because of the presence of the compound on the membrane surface. However, there was no inhibition of phagocytosis or on the subsequent release of a lysosomal enzyme into the medium. Our results are also in agreement with Hawkins (31) who in similar experiments with other drugs found the neutrophil lysosomal release mechanism to be relatively resistant to drug effects. We found in several experiments that the uptake of latex particles into PMN was not impaired by the absence or presence of penicillamine in a concentration of 400 $\mathrm{mg} /$ liter. 
The demonstration of this unique dicotomy of drug effect on leukocyte function leads one to several conclusions. New drugs which are planned for use in a disease such as RA could be tested in these systems for their possible effect on leukocyte function. If inhibition of chemotaxis but no effect on phagocytosis simliar to that seen with penicillamine is found, it would appear that drugs of this type would be less likely to cause infection as a side effect of their use in treatment.

The effect of penicillamine on the function of the polymorphonuclear leukocyte in vivo is at present being studied. However, the protocol for this clinical study is at the present time restricted to patients with Behçet's disease. We have preliminary information but since we are using the "go low, go slow" regimen most of our patients are still at the lowest end of the spectrum of therapeutic levels. The patient on the highest dosage of penicillamine $(1,000 \mathrm{mg} /$ day $)$ to date has shown after 3 mo of this level and 6 mo of total therapy a reduction of his chemotactic index to normal levels. At the onset of therapy the chemotactic index of his cells had been 137 to $413 \%$ of the normal control.

Whether or not this effect on chemotaxis is responsible for the decrease in the inflammatory activity of Behçet's disease or hypothesized in RA cannot be proven by our results. The major effect of D-penicillamine therapy has been shown to be a reduction in inflammatory joint activity. This may be a specific result of the inhibition of chemotaxis restricting the movement of the PMN into the joint. Drugs showing inhibition of chemotaxis but without an effect on phagocytosis as determined by these in vitro techniques may thus be effective and relatively safe for the treatment of RA.

\section{ACKNOWLEDGMENTS}

This investigation was supported by a grant from the Monroe County Chapter of the Arthritis Foundation.

\section{REFERENCES}

1. Jaffe, I. A. 1963. Comparison of the effect of plasmapheresis and penicillamine on the level of circulating rheumatoid factor. Ann. Rheum. Dis. 22: 71-76.

2. Day, A. T., J. R. Golding, P. N. Lee, and A. D. Butterworth. 1974. Penicillamine in rheumatoid arthritis: A long-term study. Br. Med. J. 1: 180-183.

3. Maldykowa, H., H. Chwalińska-Sadowska, S. Luft, Glinska-Urban Mikolajew, A. Odrzywolska, and H. Jaworska. 1972. Results of cuprenil (D-penicillamine) treatment in patients with rheumatoid arthritis. Rheumatologia. 10: 9-21.

4. Multicenter Trial Group. 1973. Controlled trial of $\mathrm{D}(-)$ penicillamine in severe rheumatoid arthritis. Lancet. I: 275-280.

5. Baum, J. 1974. Immunosuppressive drugs in the treatment of rheumatic diseases. J. Rheumatol. 1: 4, 355-357.

6. Kvarstein, B. 1969. A methodological study of human leukocyte adhesiveness to glass beads. Scand. J. Clin. Lab. Invest. 23: 259-270.
7. Hawkins, D., and S. Peeters. 1971. The response of polymorphonuclear leukocytes to immune complexes in vitro. Lab. Invest. 24 : 483-491.

8. Fishmann, W. H. 1963. $\beta$-Glucuronidase. In Methods of Enzymatic Analysis. H-U. Bergmeyer, editor. Academic Press Inc., New York. 869-874.

9. Wróblewski, F., and J. S. LaDue. 1955. Lactic dehydrogenease activity in blood. Proc. Soc. Exp. Biol. Med. 90 : 210-213.

10. Ignarro, L. J., T. F. Lint, and W. J. George. 1974. Hormonal control of lysosomal enzyme release from human neutrophils. Effects of autonomic agents on enzyme release, phagocytosis, and cyclic nucleotide levels. J. Exp. Med. 139: 1395-1414.

11. Kvarstein, B. 1969. The effect of temperature metabolic inhibitors, and EDTA on phagocytosis of polystyrene latex particles by human leukocytes. Scand. J. Clin. Lab. Invest. $24:$ 271-277.

12. Wagner, T., G. Abraham, and J. Baum. 1974. The roles of IgG, IgM rheumatoid factor, and their complexes in the induction of polymorphonuclear leukocyte chemotactic factor from complement. J. Clin. Invest. 53: 15031511.

13. Baum, J. 1975. Chemotaxis in human disease. In The Phagocytic Cell in Host Resistance. J. A. Bellanti and D. H. Dayton, editors. Raven Press, New York. 283293.

14. Baum, J., A. G. Mowat, and J. A. Kirk. 1971. A simplified method for the measurement of chemotaxis of polymorphonuclear leukocytes from human blood. J. Lab. Clin. Med. 77 : 501-509.

15. Jaffe, I. A. 1962. Intra-articular dissociation of rheumatoid factor. J. Lab. Clin. Med. 60: 409-421.

16. Roath, S., and R. Wills. 1974. The effect of penicillamine on lymphocytes in culture. Postgrad. Med. J. Suppl. 50 (Suppl. 2) : 56-59.

17. Huskisson, E. C., and H. Berry. 1974. Some immunological changes in rheumatoid arthritis among patients receiving penicillamine and gold. Postgrad. Med. J. Suppl. 50(Suppl. 2) : 59-61.

18. Liyanage, S. P., and H. L. F. Currey. 1972. Failure of oral D-penicillamine to modify adjuvant arthritis or immune response in the rat. Ann. Rheum. Dis. 31: 521.

19. Bluestone, R., and L. S. Goldberg. 1973. Effect of Dpenicillamine on serum immunoglobulins and rheumatoid factor. Ann. Rheum. Dis. 32: 50-52.

20. Jaffe, I., P. Merriman, and E. Ehrenfeld. 1974. Further studies of the anti-viral effect of D-penicillamine. Postgrad. Med. J. Suppl. 50 (Suppl. 2) : 50-55.

21. Ryzewski, J. 1966. The effect of cysteine on the development and the course of the post-adjuvant polyarthritis in rats. Rheumatologia. 4: 227-233.

22. Dabrowska, B. K., J. Ryźewski, M. P. Dabrowski, and A. Ryzewska. 1974. Suppression of MLC-reactivity of rat lymphocytes by L-cysteine hydrochloride. Bull. Acad. Pol. Sci. Ser. Sci. Biol. 22 : 287-291.

23. Jaffe, I. A. 1974. Round table discussion-proper use of penicillamine. Postgrad. Med. J. Suppl. 50(Suppl. 2): 80-83.

24. Brandt, L., and B. Svensson. 1975. Effect of penicillamine on peripheral-blood lymphocytes in rheumatoid arthritis. Lancet. I: 394-395.

25. Mowat, A. G., and J. Baum. 1971. Chemotaxis of polymorphonuclear leukocytes from patients with diabetes mellitus. N. Engl. J. Med. 284 : 621-627. 
26. Rosenfeld, S. I., J. Baum, R. T. Steigbigel, and J. P. Leddy. 1976. Hereditary deficiency of the fifth component of complement in man. II. Biological properties of C5-deficient human serum. J. Clin. Invest. 57: 1635-1643.

27. Berenberg, J. L., and P. A. Ward. 1973. Chemotactic factor inactivator in normal human serum. J. Clin. Invest. 52 : $1200-1206$.

28. Alper, C. A., T. P. Stossel, and F. S. Rosen. 1975. Genetic defects affecting complement and host resistance to infection. In The Phagocytic Cell in Host Resistance. J. A. Bellanti and D. H. Dayton, editors. Raven Press, New York. 127-141.
29. Becker, E. L. 1975. Enzyme activation and the mechanism of polymorphonuclear leukocyte chemotaxis. In The Phagocytic Cell in Host Resistance. J. A. Bellanti and D. H. Dayton, editors. Raven Press, New York. 1-14.

30. Austen, K. F. 1971. Inborn and acquired abnormalities of the complement system of man. Johns Hopkins Med. J. $128: 57-74$.

31. Hawkins, D. 1974. Neutrophilic leukocytes in immunologic reactions in vitro. III. Pharmacologic modulation of lysosomal constituent release. Clin. Immunol. Immunopathol. 2 : 141-152. 